\title{
Leger i tidsklemma
}

«Hvis jeg er kjip og insisterer på rettighetene mine, er jeg redd for ikke å få de morsomme oppgavene og for å få færre operasjoner.»

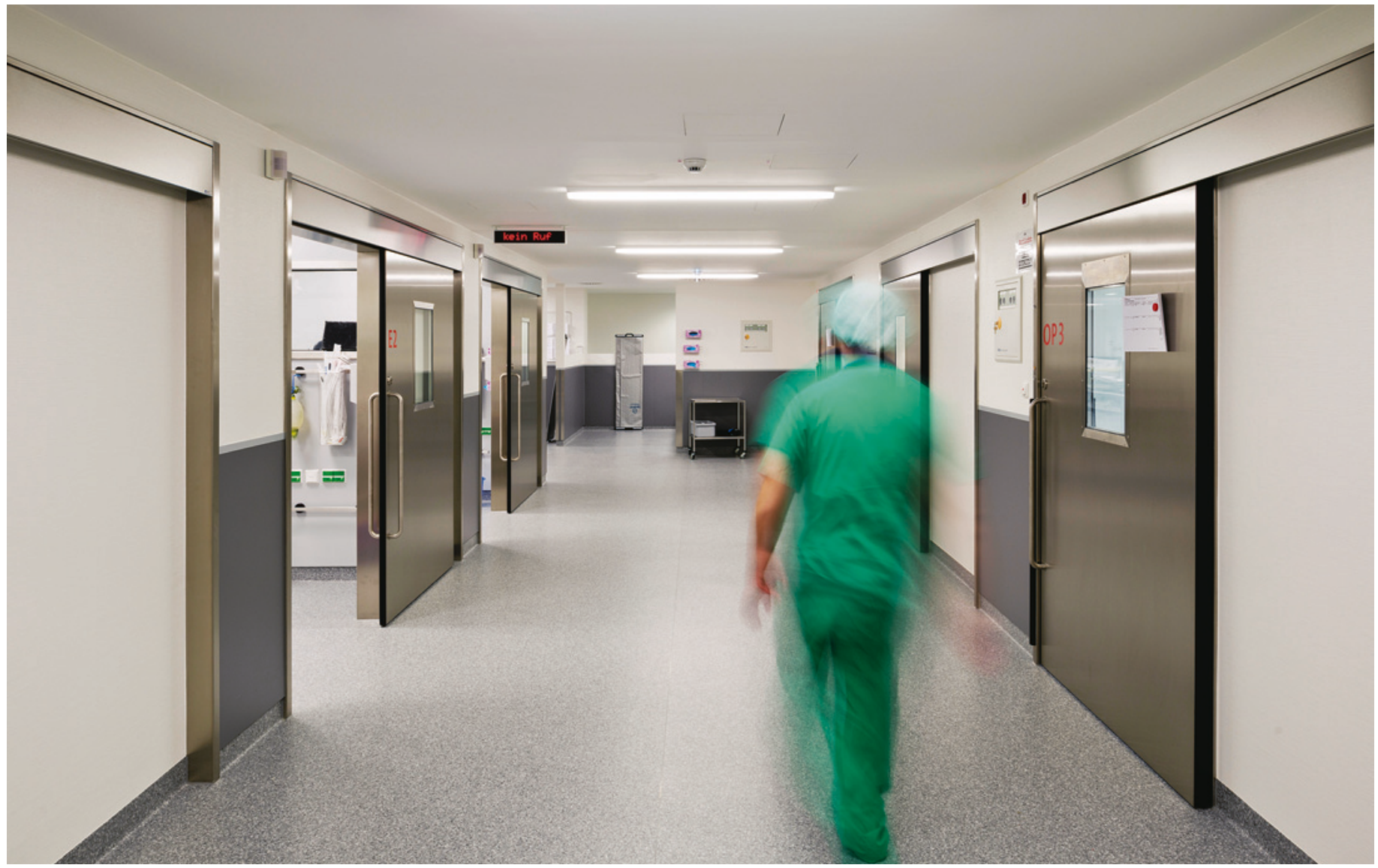

«I løpet av én maratonmåned så de hverandre tre kvelder», kunne man lese i Dagens Medisin i et intervju med et legepar (1). Paret fortalte om en krevende tidskabal med hyppig vaktbelastning og små barn hjemme. Selv om de mente at arbeidsgiver burde kunne tilby muligheter for 38-timersuker og anledning til å være hjemme med sykt barn, beskriver de at det kan oppleves som vanskelig å stå på kravene. - Det ville ha gått ut over kollegene mine hvis jeg skulle ha vært fritatt for vakter og tatt ammefri, uttalte småbarnsmoren.

En intens arbeidssituasjon, med lang arbeidsuke og høye ambisjoner om læring og utvikling, kan selvfølgelig komme i konflikt med forpliktelser på hjemmebane. Særlig kvinnelige leger har tidligere funnet dette krevende, men i nye generasjoner leger rapporterer nå menn om like mye stress i forbindelse med jobb-hjem-kabalen (2).

I denne nylig publiserte studien (2) under- søkte vi hvordan stress på grunn av (u)balanse mellom forpliktelser på jobb og hjemme ti år ut i legekarrieren påvirket legenes situasjon fem år senere. Både for menn og kvinner ga vedvarende jobb-hjem-stress gjennom femårsperioden økt risiko for utbrenthet. Sosial støtte fra kolleger viste seg imidlertid å være beskyttende, særlig for mannlige leger.

Det er fortsatt mindre vanlig at mannlige leger tilpasser jobben til hjemmesituasjonen, ved å redusere antall ukearbeidstimer eller være hjemme når barna er syke. Det kan bidra til at de mennene som vurderer å gjøre slike tilpasninger, får mindre aksept og støtte av ledere og kolleger.

Særlig når det gjelder menn, kan reduksjon $\mathrm{i}$ arbeidstid og kollegial støtte motvirke effekten av jobb-hjem-stress (2). For kvinnenes del er en godt avpasset arbeidssituasjon til og med vist å kunne være en ressurs for hjemmesituasjonen (3).

Aksept fra kolleger og tilrettelegging av arbeidssituasjonen vil kunne gi en tilpasset, men likevel lærerik arbeidssituasjon i bedre balanse med forpliktelser på hjemmefronten både for menn og kvinner.

\section{Karin Isaksson Rø}

LEFO - Legeforskningsinstituttet

\section{Litteratur}

1. Hanger MR. Leger vil gifte seg med leger. http://www.dagensmedisin.no/artikler/2014/03/14/ leger-vil-gifte-seg-med-leger/ (28.4.2016).

2. Hertzberg TK, Rø KI, Vaglum PJW et al. Workhome interface stress: an important predictor of emotional exhaustion 15 years into a medical career. Ind Health 2016: 54: 139-48.

3. Langballe EM, Innstrand ST, Aasland OG et al. The predictive value of individual factors, work-related factors, and work-home interaction on burnout in female and male physicians: a longitudinal study. Stress Health 2011; 1: 73-87. 